\title{
Effect of Internal Curing with Superabsorbent Polymers on Bond Behavior of High-Strength Concrete
}

\author{
Xiao Lei, ${ }^{1}$ Rui Wang, ${ }^{1}$ Hanwan Jiang $\mathbb{D}^{2},{ }^{2}$ Faxiang Xie, ${ }^{1}$ and Yanni Bao ${ }^{3}$ \\ ${ }^{1}$ College of Civil and Transportation Engineering, Hohai University, 1 Xikang Road, Nanjing, Jiangsu 210098, China \\ ${ }^{2}$ College of Engineering, Mathematics and Science, Department of Civil Engineering, University of Wisconsin Platteville, \\ 1 University Plaza, Platteville, WI 53818, USA \\ ${ }^{3}$ Tongji Architectural Design (Group) Co. Ltd., Shanghai 20092, China \\ Correspondence should be addressed to Hanwan Jiang; jianghan@uwplatt.edu
}

Received 18 November 2020; Revised 2 December 2020; Accepted 22 December 2020; Published 31 December 2020

Academic Editor: Haohui Xin

Copyright ( $) 2020$ Xiao Lei et al. This is an open access article distributed under the Creative Commons Attribution License, which permits unrestricted use, distribution, and reproduction in any medium, provided the original work is properly cited.

\begin{abstract}
High-strength concrete (HSC) is widely used in engineering due to its high strength and durability. However, because of its low water-to-cement ratio, external curing water hardly enters the dense internal structure of HSC so that high self-desiccation shrinkage often takes place. As a result, superabsorbent polymers (SAP) are added as an internal curing material to effectively reduce the shrinkage of high-performance concrete. Meanwhile, the bond performance between reinforcing steel and SAP HSC concrete remains unknown. In this paper, the bond performance of HSC mixed with SAP is studied by pull-out tests, and the results were obtained as follows: (1) the bond strength of HSC mixed with SAP increased first and then decreased with the increase of SAP content; (2) the slip at ultimate bond strength of HSC with SAP decreased with the increase of compressive strength; (3) a prediction model of the stress-slip relationship between steel rebars and HSC was established.
\end{abstract}

\section{Introduction}

High-strength concrete has higher strength and durability than conventional concrete due to its low water-to-cement ratio, denser internal structure, and low permeability [1]. However, autogenous shrinkage may take place when the water-to-cement ratio is below the critical level, resulting in cracking and reduction of the structure's serviceability [2-5]. Hence, internal curing has been employed to prevent autogenous shrinkage in high-strength concrete by replacing a percentage of normal-weight aggregates with lightweightweight aggregates $[6,7]$, superabsorbent polymer (SAP), or other expansive materials $[8,9]$. SAP has been extensively studied due to its advantages of being able to mitigate autogenous shrinkage and prevent self-desiccation [10-15]. Multiple studies have proved that SAP can effectively reduce the self-shrinkage of HSC [16-18] while there is no consensus on the influence of SAP on the compressive strength of HSC. Some tests found that SAP would reduce the compressive strength of HSC [19-22], but some other tests found that SAP would increase the compressive strength of HSC [23-26]. It is reported that SAP content is one of the factors that affect HSC's compressive strength [27]. While there are many factors that influence compressive strength of HSC such as the amount of compensated water, type and SAP particle size, the absorption, desorption kinetic of SAPs, and the interfacial properties between cement matrix and SAPs, the authors only focus on the effect of SAP content on compressive strength of HSC in this study.

Meanwhile, as a key parameter for structural design, bond strength for HSC with SAP added has not been studied yet. Although there were many studies published on the bond strength of normal reinforced concrete [28-36] as well as high-strength concrete [37-42], the law of bond strength and the stress-slip relationship between HSC mixed with SAP and reinforcing steel remain unclear. The stress-slip relationship of concrete is usually obtained from pull-out tests. Various stress-slip models for normal concrete and high-performance concrete have been developed in many studies [41-51]. However, the stress-slip response for high- 
strength concrete mixed with SAP is still unknown. In this paper, an experimental study has been carried out aimed at establishing SAP content and compressive strength relationship, SAP content and HSC bond strength relationship, and the stress-slip model for HSC with SAP.

\section{Experimental Investigation}

2.1. Material Properties. The cement used in this test is P.O. 42.5 Portland cement with chemical composition shown in Table 1. Medium coarse sand and $5-16 \mathrm{~mm}$ continuous graded gravel were mixed with the cement to create concrete with a compression strength of $50 \mathrm{MPa}$. High efficiency polycarboxylate superplasticizer was added as a water reducing agent. Drying and absorbing states of SAP are shown in Figure 1. Standard structural rebars are $16 \mathrm{~mm}$ in diameter, shown in Figure 2. In Theory, the internal curing water should be the same for same water-to-cement ratio. However, when SAP is added, water is partially absorbed such that more water is needed in addition to that for internal curing. Therefore, the internal curing water is set to be 20 times of the SAP content.

The mixture proportions of concrete used in the test are shown in Table 2.

2.2. Required Internal Curing Water. In order to ensure that the cement can reach the maximum hydration level, the internal curing water amount can be calculated according to the following equation [52] :

$$
M_{i c}=C_{f} \times C S \times \alpha_{\max },
$$

where $M_{i c}$ is internal curing water mass required for complete hydration of cement; $C_{f}$ is the cement mass $(\mathrm{kg} /$ $\mathrm{m}^{3}$ ); CS is the shrinkage of cement when it reaches $100 \%$ hydration; for general cement, it is 0.07 ; and $\alpha_{\max }$ is the maximum hydration degree when all water in SAP is used for cement hydration without evaporation loss; generally, it is $[\mathrm{W} / \mathrm{C}] / 0.36$ (when $\mathrm{W} / \mathrm{C} \leq 0.36$ ).

According to the theoretical calculation, the internal curing water amount is $33.12 \mathrm{~kg} / \mathrm{m}^{3}$, but considering that different SAP contents were designed in the test, the final internal curing water amount of S0, S1, S2, S3, and S8 was determined to be $0,10.2,20.4,30.6$, and $81.6 \mathrm{~kg} / \mathrm{m}^{3}$, respectively.

\subsection{Concrete Preparation for Compressive Strength and Pull-} Out Test. A total of 6 specimens for pull-out test were made as shown in Figure 3. The rebar was embedded centrically in the $150 \mathrm{~mm} \times 150 \mathrm{~mm} \times 150 \mathrm{~mm}$ concrete cube. The standard 28-day strength of the concrete is $50 \mathrm{MPa}$. The embedment length of the rebar in the concrete block is 3 times of rebar diameter $(48 \mathrm{~mm})$. The rebar was sheathed with PVC pipes for debonding on both ends of the concrete block at a length of $34 \mathrm{~mm}$ and $68 \mathrm{~mm}$, respectively. A shorter bond length 3 times rebar diameter instead of typically used 5 times rebar diameter [53] was adopted in order to obtain a complete stress-slip curve and prevent splitting.
Three $150 \mathrm{~mm}$ concrete cubes were set for the compressive strength test. The concrete mixing is followed in a sequence. First of all, cement, coarse and fine aggregate, and dry SAP were put together and mixed for $30 \mathrm{~s}$; then half of the water and the water reducing agent were added and mixed for another $2 \mathrm{~min}$; after that, the remaining half of the water and the water reducing agent were poured and mixed for additional $2 \mathrm{~min}$. Once the mixing was completed, the mixture was immediately poured into molds. The specimens have been cured for 28 days to achieve desirable strength.

2.4. Experimental Process. A hydraulic universal testing machine was used for the test, and an LVDT sensor was set on the specimen to measure the relative slip of steel bar and concrete, as shown in Figure 4(a). The test was controlled by displacement, and the loading rate was $0.3 \mathrm{~mm} / \mathrm{min}$. The test ended when the steel bar was pulled out or broken, the concrete specimen was damaged or reaches the specified displacement. Dynamic data collection was used to record the load value and the reading of the LVDT. The failure mode of all tests is deemed to be split failure from the visual inspection shown in Figure 4(b).

\section{Experiment Results}

3.1. Effect of SAP on Compressive Strength of HSC. The compressive strength of HSC with different content of SAP is shown in Figure 5. It indicates that a small amount of SAP can increase the compressive strength of HSC, but when the content exceeded the peak value, the compressive strength was reduced. When the SAP content was $0.1 \%$ of cement mass, the compressive strength of concrete increases by $4.55 \%$; when the SAP content was $0.2 \%, 0.3 \%$, and $0.8 \%$ of cement mass, the compressive strength of concrete decreased by $9.84 \%, 20.91 \%$, and $33.33 \%$, respectively. The amount of SAP needed to achieve maximum compressive strength is a trade-off analysis. SAP reduces the shrinkage in concrete and improves cement hydration which helps increase the compressive strength. Meanwhile, the addition of SAP increases water diversion and porosity and therefore results in decreased compressive strength. This experiment showed that the peak of compressive strength had been achieved with $0.1 \%$ SAP addition.

The following equation was created to best fit the data points in Figure 5 with the goodness of fit $R^{2}=0.99$ :

$$
f_{c u}=f_{c, 28 d} \cdot \frac{63.89 x^{2}-7.01 x+3.07}{100 x^{2}-11.93 x+3.07}
$$

where $f_{c u}$ is the compressive strength of SAP concrete, MPa; $f_{c, 28 d}$ is the 28-day compressive strength of ordinary concrete, $\mathrm{MPa} ; x$ is the SAP content, $\%$.

The calculated and measured compressive strength of SAP concrete are listed in Table 3. It shows that the differences between the calculated and measured values are minimal so that equation (2) can be adopted to represent the SAP content-compressive relationship. 
TABLE 1: Chemical composition of cement.

\begin{tabular}{lc}
\hline Chemical composition & Content (\%) \\
\hline $\mathrm{SiO}_{2}$ & 19.9 \\
$\mathrm{Al}_{2} \mathrm{O}_{3}$ & 4.6 \\
$\mathrm{Fe}_{2} \mathrm{O}_{3}$ & 3.0 \\
$\mathrm{CaO}$ & 64.6 \\
$\mathrm{SO}_{3}$ & 2.37 \\
$\mathrm{Na}_{2} \mathrm{O}$ & 0.06 \\
$\mathrm{~K}_{2} \mathrm{O}$ & 0.65 \\
$\mathrm{MgO}$ & 0.78 \\
$\mathrm{Cl}^{-}$ & 0.01 \\
\hline
\end{tabular}

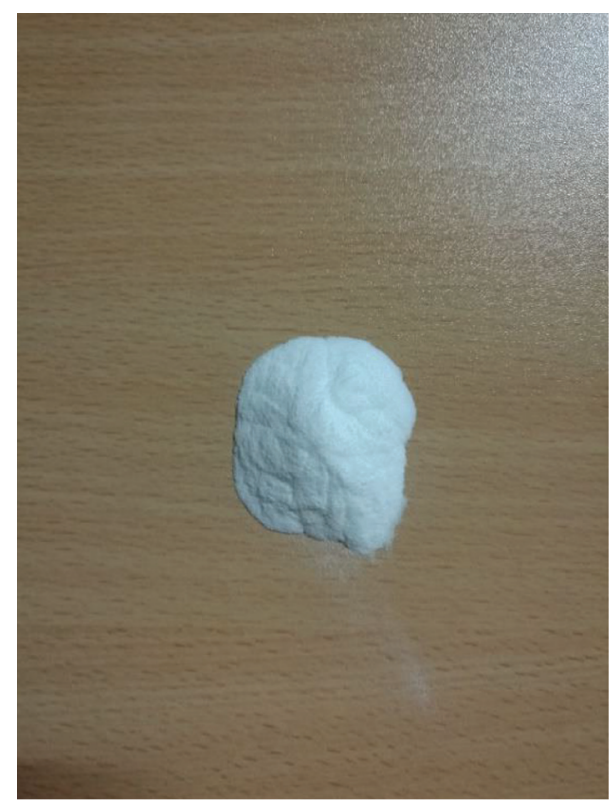

(a)

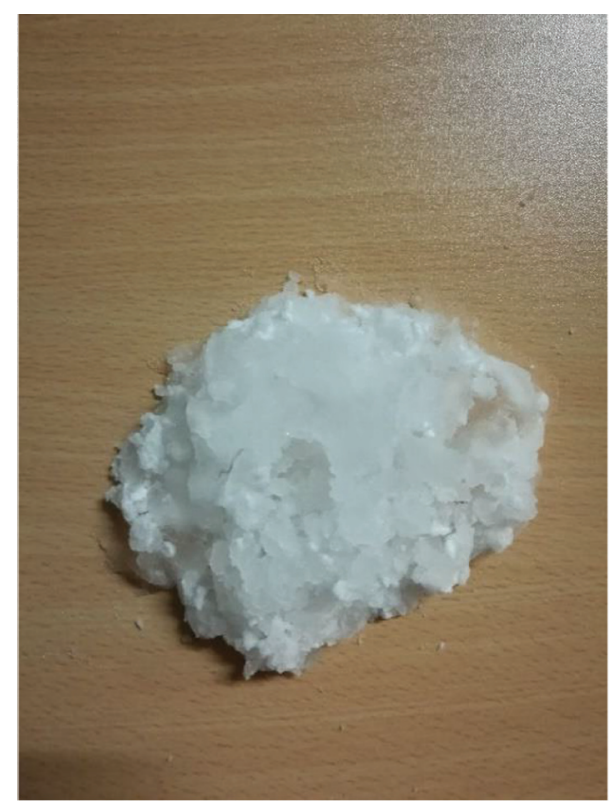

(b)

FIGURE 1: Superabsorbent polymer (SAP): collapsed (a); swollen (b).

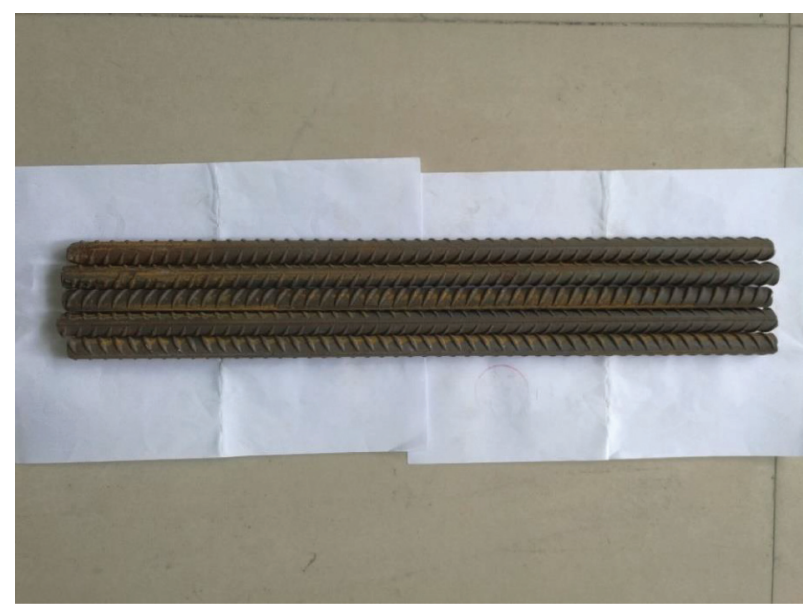

FIGURE 2: Rebars used in the experiments.

TABLE 2: Mixture proportions of concrete.

\begin{tabular}{lccccc}
\hline Serial number & S0 & S1 & S2 & S3 & S8 \\
\hline W/C & 0.334 & 0.334 & 0.334 & 0.334 & 0.334 \\
Cement $\left(\mathrm{kg} / \mathrm{m}^{3}\right)$ & 510 & 510 & 510 & 510 & 510 \\
Water $\left(\mathrm{kg} / \mathrm{m}^{3}\right)$ & 170 & 170 & 170 & 170 & 170 \\
Internal curing water $\left(\mathrm{kg} / \mathrm{m}^{3}\right)$ & 0 & 10.2 & 20.4 & 30.6 & 81.6 \\
Coarse aggregate $\left(\mathrm{kg} / \mathrm{m}^{3}\right)$ & 1131 & 1131 & 1131 & 1131 & 1131 \\
Fine aggregate $\left(\mathrm{kg} / \mathrm{m}^{3}\right)$ & 636 & 636 & 636 & 636 & 636 \\
Water reducing agent $\left(\mathrm{kg} / \mathrm{m}^{3}\right)$ & 2.6 & 2.6 & 2.6 & 2.6 & 2.6 \\
SAP $\left(\mathrm{kg} / \mathrm{m}^{3}\right)$ & 0 & 0.51 & 1.02 & 1.53 & 4.08 \\
\hline
\end{tabular}

"S" in the serial number stands for SAP content.

3.2. Effect of SAP on Bond Strength of HSC. The equation for calculating the bond strength is simply to use the pull-out force divided by the contact area around the rebar as shown in the following equation:

$$
\tau_{u}=\frac{P_{u}}{\pi d l_{d}},
$$

where $\tau_{u}$ is the bond strength, MPa; $P_{u}$ is the pull-out force, $\mathrm{N} ; d$ is the diameter of the steel bar, $\mathrm{mm}$; and $l_{d}$ is the bond length, $\mathrm{mm}$.

The bond strength for HSC with different SAP content is tested and shown in Table 4. It can be seen from the table that a small amount of SAP could increase the bond strength of HSC, but if adding more than $0.1 \%$ of SAP, the bond strength was reduced. When the SAP content was $0.1 \%$ of the cement mass, the bond strength of concrete increased by $8.92 \%$; when the SAP content was $0.2 \%, 0.3 \%$, and $0.8 \%$ of the cement mass, the bond strength of concrete decreased by $5.98 \%, 14.55 \%$, and $25.24 \%$, respectively.

The experimental results show that the bond strength variations with SAP content in HSC is similar to that of compressive strength. It is worth noting that the addition of SAP made the bond strength of concrete increase more than compressive strength (Figure 6). For example, adding 0.1\% of SAP caused $4.55 \%$ increase in compressive strength and $8.92 \%$ in bond strength. Similarly, adding $0.2 \%, 0.3 \%$, and $0.8 \%$ SAP caused $9.84 \%, 20.91 \%$, and $33.33 \%$ drawdown in 


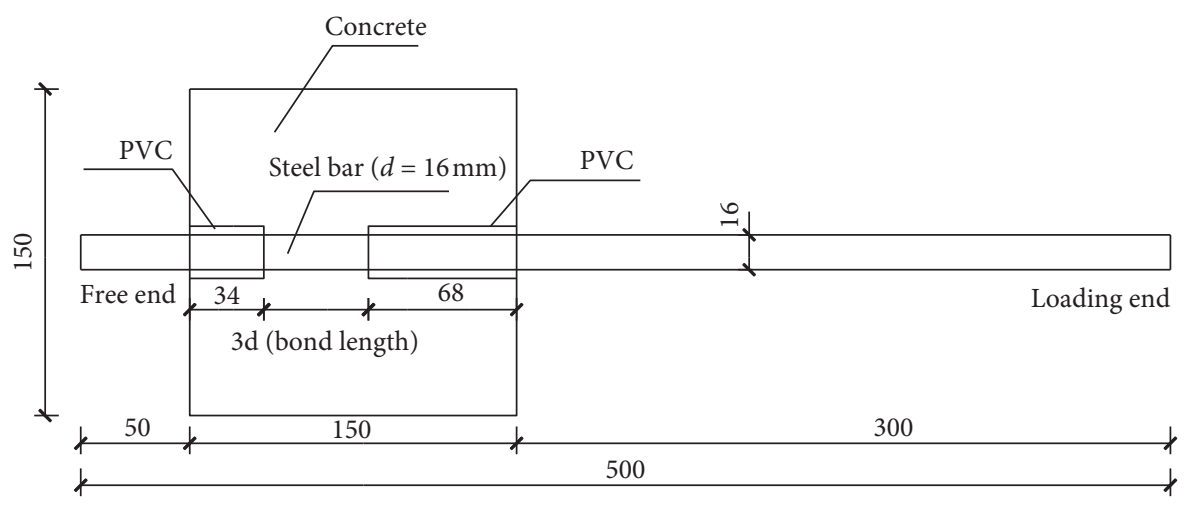

FIgUre 3: Pull-out test specimen (all units in millimeters, $d$ is the rebar diameter).

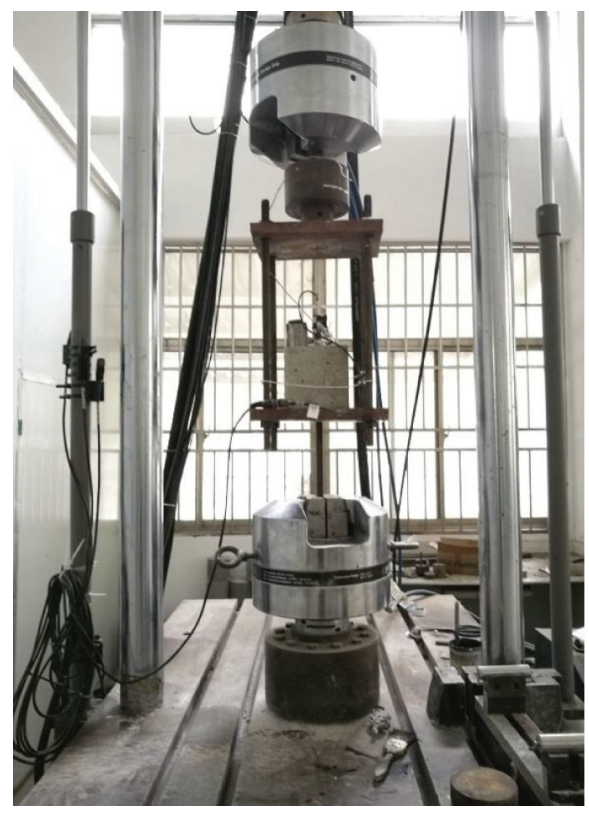

(a)

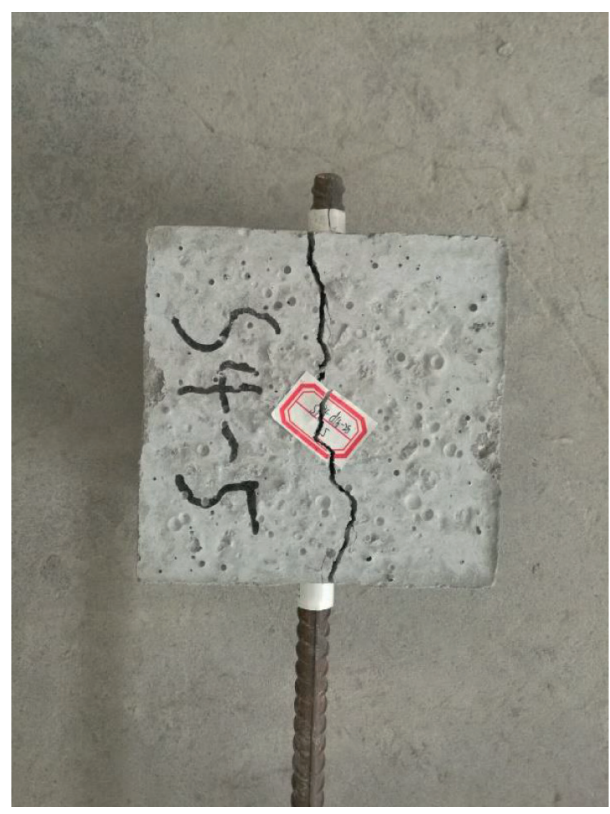

(b)

Figure 4: Pull-out test device. (a) Test instrument. (b) Split at failure.

compressive strength and $5.98 \%, 14.55 \%$, and $25.24 \%$ decrease in bond strength. The correlation between bond strength and compressive strength is discussed in Section 3.3 .

3.3. Relationship between Compressive Strength and Bond Strength of Concrete Mixed with SAP. There have been a number of studies carried out on the relationship between bond strength and compressive strength of concrete and rebar. In these studies, bond strength is expressed in terms of the exponent of compressive strength [29, 33-35, 39-42]:

$$
\tau_{b}=a\left(f_{c}^{\prime}\right)^{b}
$$

where $\tau_{b}$ is the bond strength in $\mathrm{MPa}, f_{c}^{\prime}$ is the cylinder compressive strength in $\mathrm{MPa}$, and $a$ and $b$ are the constants.

The authors of the literature $[29,33]$ studied the relationship between cylinder compressive strength and bond strength accounting for factors such as the minimum thickness of protective layer, diameter of steel bars, and bond length of steel bars. The empirical equation and value for parameters $a$ and $b$ were given:

$$
\begin{aligned}
& a=A+B \frac{c_{\min }}{d_{b}}+C \frac{d_{b}}{l_{d}}, \\
& b=0.5,
\end{aligned}
$$

where $c_{\min }$ is the minimum thickness of protective layer, $\mathrm{mm} ; d_{b}$ is the diameter of steel bars, $\mathrm{mm} ; l_{d}$ is the bond length, $\mathrm{mm}$; and $A, B$, and $C$ are the constants.

The research results of literature $[29,33]$ are shown in Table 5.

In literature $[34,35,39]$, the relationship between cylinder compressive strength and bond strength under the influence of minimum thickness of protective layer, 


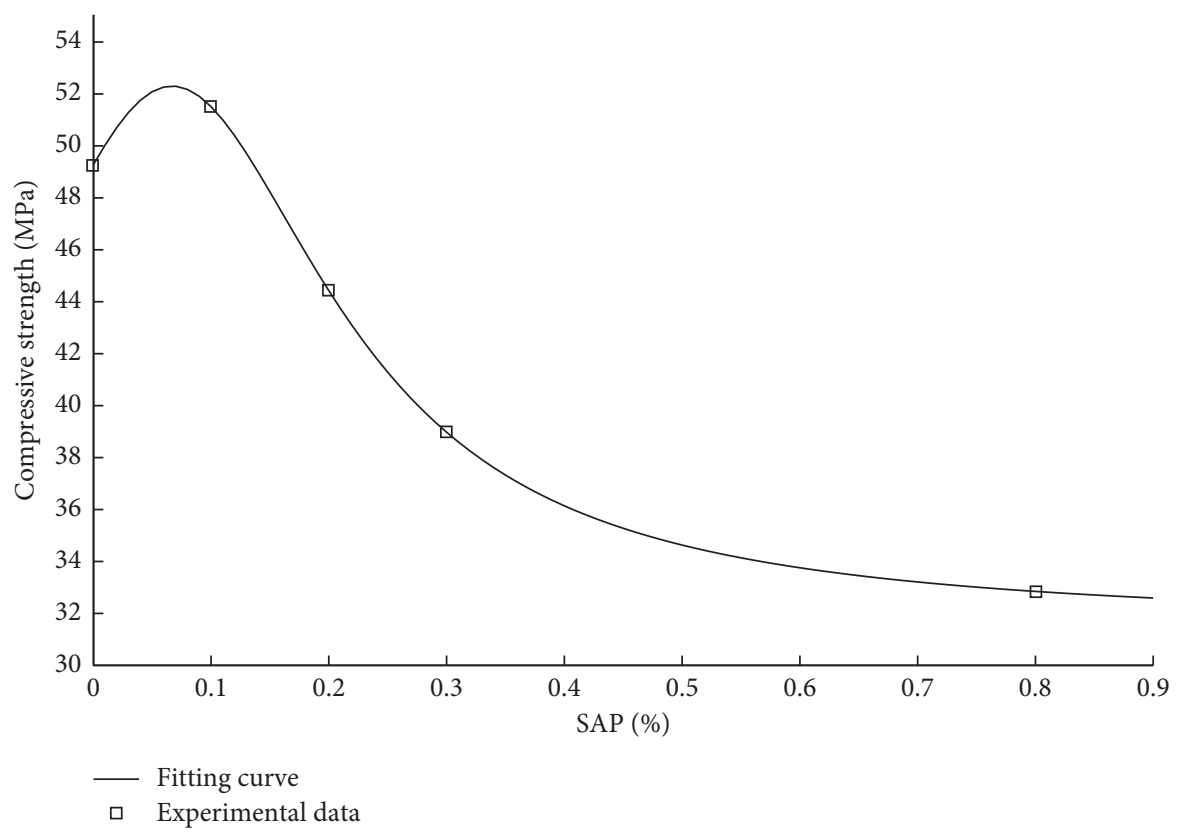

FIgURE 5: Relationship between SAP content and compressive strength.

TABLE 3: Theoretical and experimental results of compressive strength of SAP concrete.

\begin{tabular}{lccc}
\hline SAP dosage $(\%)$ & Test compressive strength $(\mathrm{MPa})$ & Theoretical compressive strength $(\mathrm{MPa})$ & Error \\
\hline 0 & 49.27 & 49.27 & 0 \\
0.1 & 51.51 & 51.51 & 0 \\
0.2 & 44.42 & 44.43 & 0.02 \\
0.3 & 38.97 & 38.98 & 0.03 \\
0.8 & 32.85 & 32.85 & 0 \\
\hline
\end{tabular}

TABLE 4: Bonding strength of specimens.

\begin{tabular}{lcc}
\hline SAP dosage $(\%)$ & Bond strength $(\mathrm{MPa})$ & Slip corresponding to bond strength $(\mathrm{mm})$ \\
\hline 0 & 36.76 & 0.833 \\
0.1 & 40.04 & 0.836 \\
0.2 & 34.56 & 0.986 \\
0.3 & 31.41 & 1.005 \\
0.8 & 27.48 & 1.126 \\
\hline
\end{tabular}

maximum thickness of protective layer, diameter of steel bars, bond length of steel bars, and area of steel bars was studied; a different function and value for $a$ and $b$ were derived and shown in the following equations:

$$
\begin{aligned}
& a=\left[A l_{d}\left(c_{\min }+0.5 d_{b}\right)+B A_{b}\right]\left(0.1 \frac{c_{\max }}{c_{\min }}+0.9\right)\left(\pi d_{b} l_{d}\right)^{-1} \\
& b=0.25
\end{aligned}
$$

where $l_{d}$ is the bond length, $\mathrm{mm} ; c_{\min }$ is the minimum thickness of protective layer, $\mathrm{mm} ; d_{b}$ is the diameter of steel bars, $\mathrm{mm} ; A_{b}$ is the area of steel bars; $c_{\max }$ is the maximum thickness of protective layer, $\mathrm{mm}$; and $A$ and $B$ are the constants.
The research results of literature $[34,35,39]$ are shown in Table 6.

In literature [39], experimental studies were conducted on concrete specimens with strength up to $90 \mathrm{MPa}$, and the expressions of $a$ and $b$ values were obtained as shown below:

$$
\begin{aligned}
& a=4.1, \\
& b=0.5,
\end{aligned}
$$

In literature [41], bond strength of high-strength concrete was studied, and the expressions of $a$ and $b$ values obtained are shown in the following equation:

$$
\begin{gathered}
a=1.65, \\
b=0.7 .
\end{gathered}
$$




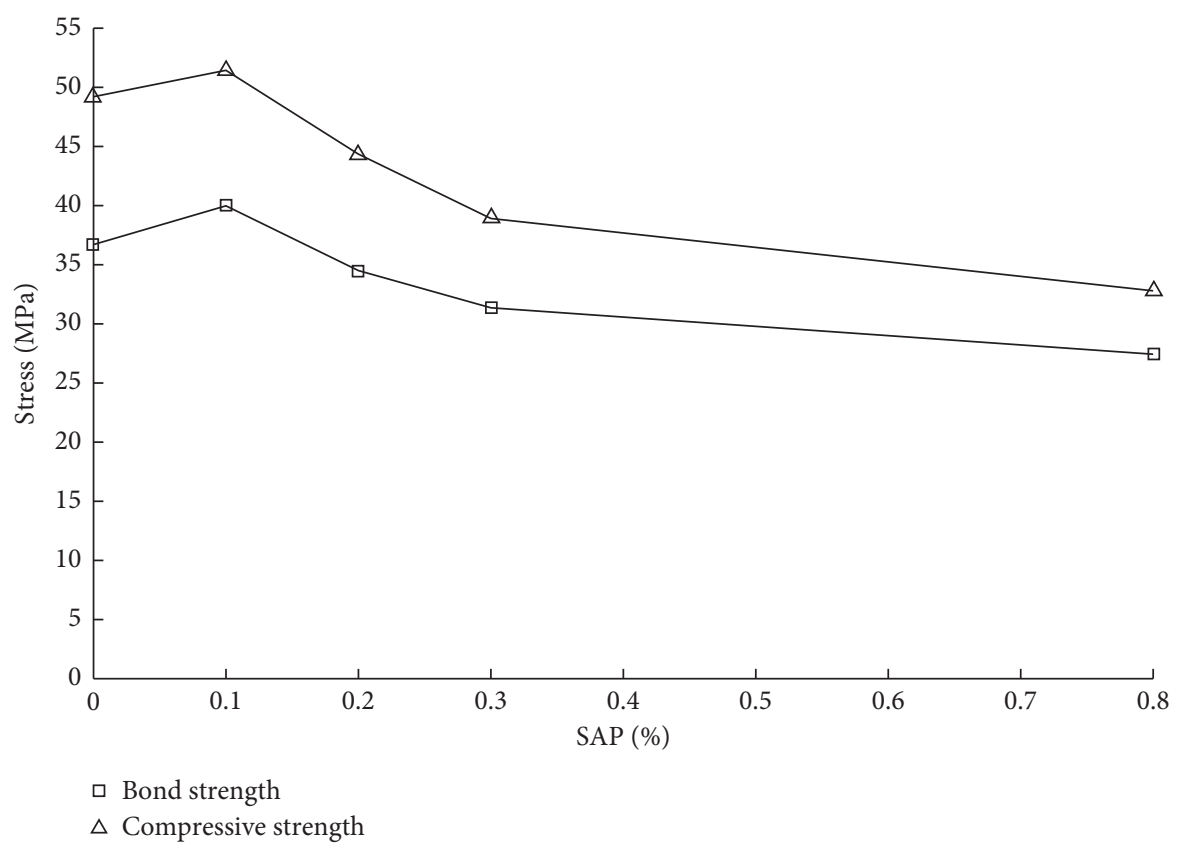

FIgURE 6: Comparison of bond strength and compressive strength of concrete mixed with SAP.

TABle 5: Values of $A, B$, and $C$ in different tests.

\begin{tabular}{lccc}
\hline Serial number & $A$ & $B$ & $C$ \\
\hline Orangun [33] & 0.10 & 0.25 & 4.15 \\
Chapman [29] & 0.29 & 0.282 & 4.734 \\
\hline
\end{tabular}

TABLe 6: Values of $A$ and $B$ in different tests.

\begin{tabular}{lcc}
\hline Serial number & $A$ & $B$ \\
\hline Darwin [34] & 1.5 & 51 \\
Zuo [39] & 1.43 & 56.2 \\
ACI [35] & 1.43 & 57.4 \\
\hline
\end{tabular}

According to literature [44], the ratio of compressive strength of the $150 \mathrm{~mm}$ cube to that of the standard cylinder is 0.8 , so the cylinder compressive strength $f_{c}^{\prime}$ of the concrete with $0,0.1 \%, 0.2 \%, 0.3 \%$, and $0.8 \%$ SAP content in this test is $39.42,41.21,35.54,31.18$, and $26.28 \mathrm{MPa}$, respectively.

The relationship between the cylinder compressive strength and bond strength obtained from the above calculation results and this test is shown in Figure 7.

As seen in Figure 7, the models from the listed literatures are not consistent with testing data for concrete mixed with SAP. Equation (4) was used to best fit the data, and the values for a and $b$ were obtained $(a=2.03, b=0.8)$ with $R^{2}=0.97$. Hence, the bond strength and the cylinder compressive strength relationship of SAP concrete can be expressed as

$$
\tau_{b}=2.03\left(f_{c}^{\prime}\right)^{0.8}
$$

where $\tau_{b}$ is the bond strength, $\mathrm{MPa} ; f_{c}^{\prime}$ is the cylinder compressive strength, $\mathrm{MPa}$.

The calculated and measured bond strengths for concrete specimens with various SAP content are shown in
Table 7. Since the difference between the two is within $5 \%$, equation (9) is suitable for bond strength evaluation.

Substituting equation (2) into equation (9), the bond strength can be written as

$$
\tau_{b}=2.03 \cdot\left[0.8 \cdot f_{c, 28 d} \cdot \frac{63.89 x^{2}-7.01 x+3.07}{100 x^{2}-11.93 x+3.07}\right]^{0.8},
$$

where $\tau_{b}$ is the bond strength, $\mathrm{MPa} ; f_{c, 28 d}$ is the 28-day compressive strength of ordinary concrete $(\mathrm{MPa})$; and $x$ is the SAP content, \%. The factor of 0.8 in the bracket is to convert cylinder strength to cube strength.

3.4. Slip and Compressive Strength Relationship. Shen et al. [42] proposed a nonlinear relationship between slip at ultimate bond stress and compressive strength based on their test data. Similar trend was observed in the experiment with SAP concrete. Hence, the nonlinear model in literature [42] is adopted in this study as shown below:

$$
s_{0}=\frac{m}{f_{c}^{\prime}+n}
$$

where $s_{0}$ is the slip at ultimate bond stress, $\mathrm{mm} ; f_{c}^{\prime}$ is the cylinder compressive strength, $\mathrm{MPa} ; m$ and $n$ are the constants.

The slip at ultimate bond stress of concrete mixed with SAP in this test is shown in Figure 8. The factors of $m$ and $n$ in equation (11) were found to be $m=48.74$ and $n=16.79$ through data fitting with goodness of fit $R^{2}=0.93$. Then the relationship between the slip at ultimate bond stress $s_{0}$ and cylinder compressive strength $f_{c}^{\prime}$ can be written as

$$
s_{0}=\frac{48.74}{f_{c}^{\prime}+16.79}
$$




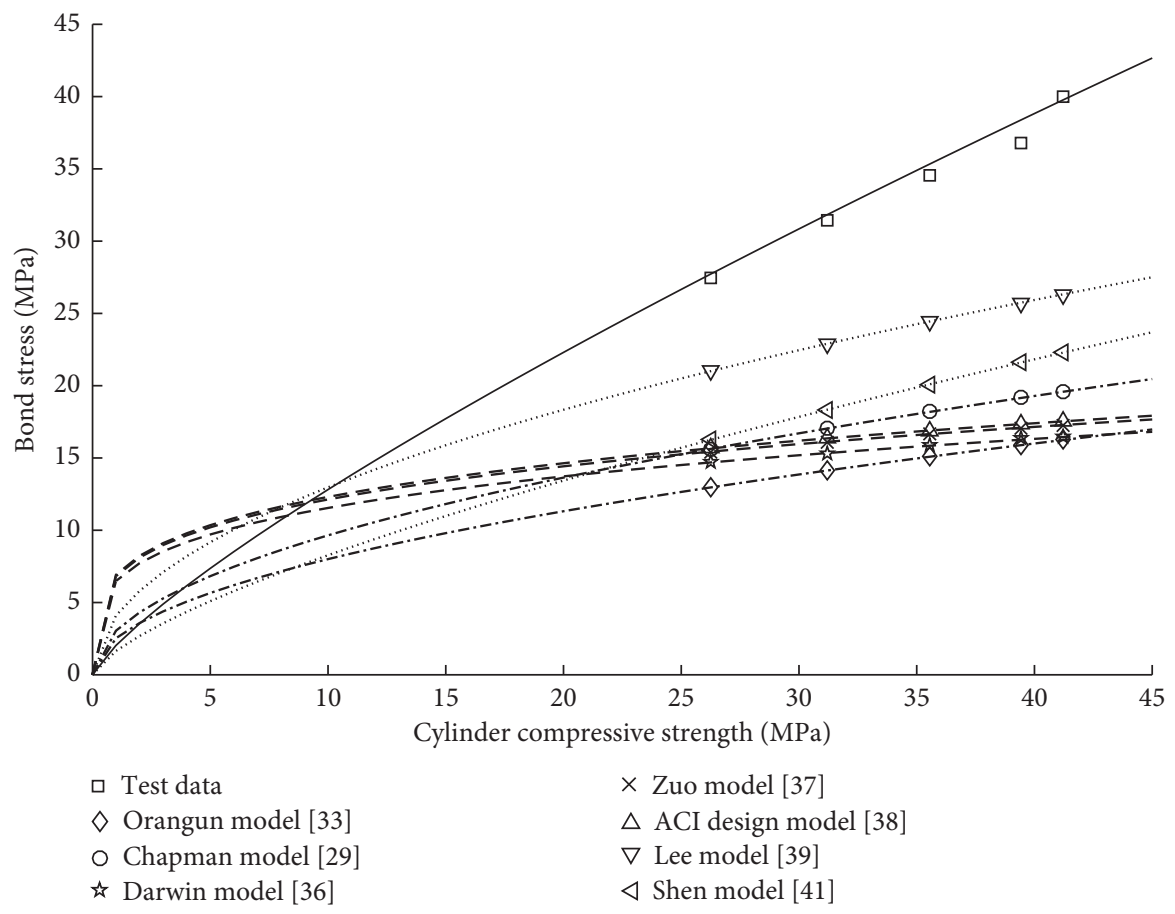

FIGURE 7: Relationship between bond strength and cylinder compressive strength of different models.

TABLE 7: Theoretical and experimental results of bond strength of SAP concrete.

\begin{tabular}{lccc}
\hline SAP content (\%) & Test bond strength $(\mathrm{MPa})$ & Theoretical bond strength $(\mathrm{MPa})$ & Error \\
\hline 0 & 36.76 & 38.37 & 4.38 \\
0.1 & 40.04 & 39.76 & 0.70 \\
0.2 & 34.56 & 35.33 & 2.23 \\
0.3 & 31.41 & 31.82 & 1.31 \\
0.8 & 27.48 & 27.75 & 0.98 \\
\hline
\end{tabular}

Then the tested and theoretical slip from equation (12) at ultimate bond stress for HSC with various SAP contents are listed and compared in Table 8.

\subsection{The Prediction Model of Stress-Slip Relationship between} Steel Bars and HSC Mixed with SAP. Various stress-slip models have been developed in the past two decades [41-51] showing that there is a clear relationship between bond stress and slip. In this study, the BPE model [51] was used:

$$
\tau=\tau_{\max }\left(\frac{s}{s_{0}}\right)^{\alpha} .
$$

It can also be expressed as

$$
\frac{\tau}{\tau_{\max }}=\left(\frac{s}{s_{0}}\right)^{\alpha},
$$

where $\tau$ is the bond stress value, $\mathrm{MPa} ; s$ is the slip corresponding to bond stress, $\mathrm{mm}$; $\tau_{\max }$ is the ultimate bond strength, $\mathrm{MPa} ; s_{0}$ is the slip at ultimate bond strength, $\mathrm{mm}$; and $\alpha$ is a constant.

Performing best fitting analysis, $\alpha$ values for SAP content of $0,0.1 \%, 0.2 \%, 0.3 \%$, and $0.8 \%$ were found to be 0.2477 , $0.1367,0.19,0.2101$, and 0.1615 , respectively, as shown in
Figure 9. Then the mean of the five numbers 0.1892 was taken for the finalized stress-slip relationship of SAP concrete as shown in the following equation:

$$
\tau=\tau_{\max }\left(\frac{s}{s_{0}}\right)^{0.1892}
$$

Combined with equation (2), equation (9), equation (10), and equation (13), bonding performance of UPC with SAP can be expressed as follows:

$$
\begin{aligned}
f_{c u} & =f_{c, 28 d} \cdot \frac{63.89 x^{2}-7.01 x+3.07}{100 x^{2}-11.93 x+3.07} \\
f_{c}^{\prime} & =0.8 f_{c u}, \\
\tau_{\max } & =2.03\left(f_{c}^{\prime}\right)^{0.8} \\
s_{0} & =\frac{48.74}{f_{c}^{\prime}+16.79}, \\
\tau & =\tau_{\max }\left(\frac{s}{s_{0}}\right)^{0.1892},
\end{aligned}
$$




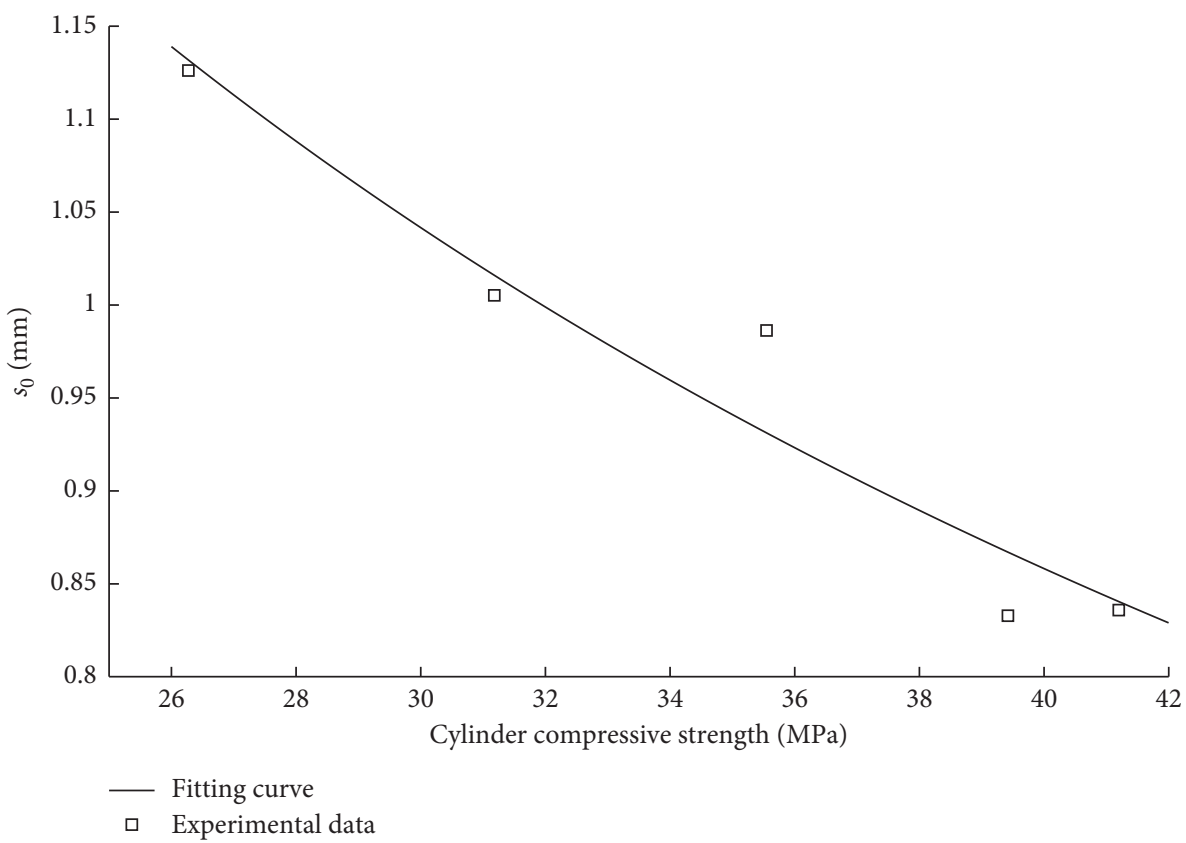

Figure 8: Relationship between slip at ultimate bond stress and cylinder compressive strength.

TABLE 8: Theoretical and experimental results of slip at ultimate bond stress for HSC with various SAP contents.

\begin{tabular}{lccc}
\hline SAP dosage (\%) & Tested slip at ultimate bond stress $(\mathrm{mm})$ & Theoretical slip at ultimate bond stress $(\mathrm{mm})$ by equation $(12)$ & Error $(\%)$ \\
\hline 0 & 0.833 & 0.867 & 4.08 \\
0.1 & 0.836 & 0.840 & 0.48 \\
0.2 & 0.986 & 0.931 & 5.58 \\
0.3 & 1.005 & 1.016 & 1.09 \\
0.8 & 1.126 & 1.132 & 0.53 \\
\hline
\end{tabular}

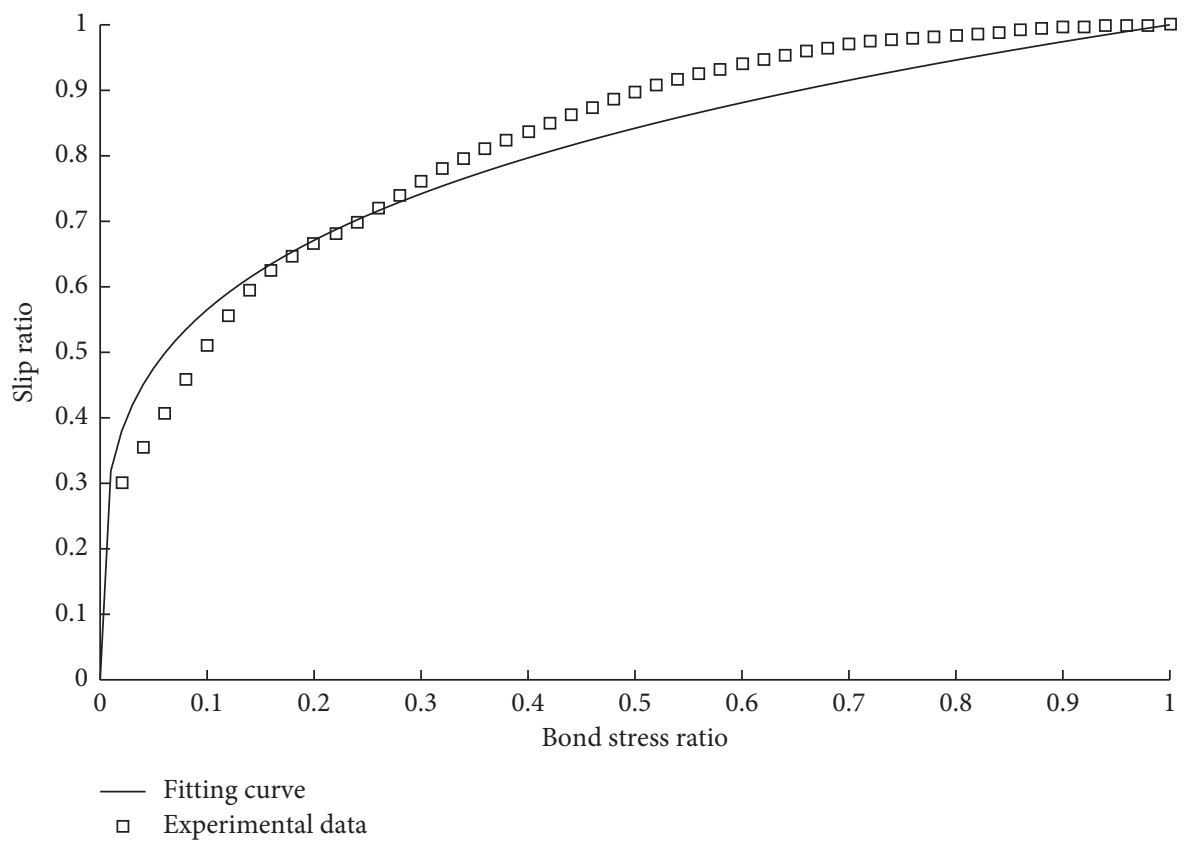

(a)

Figure 9: Continued. 


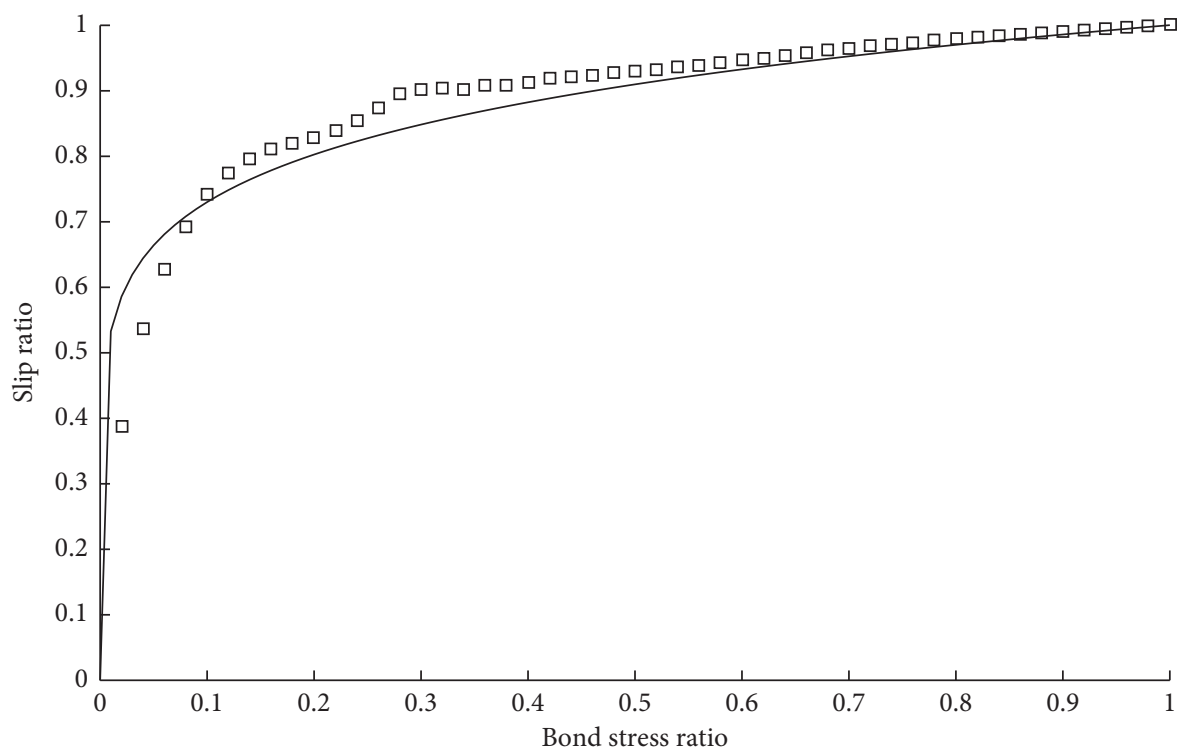

- Fitting curve

口 Experimental data

(b)

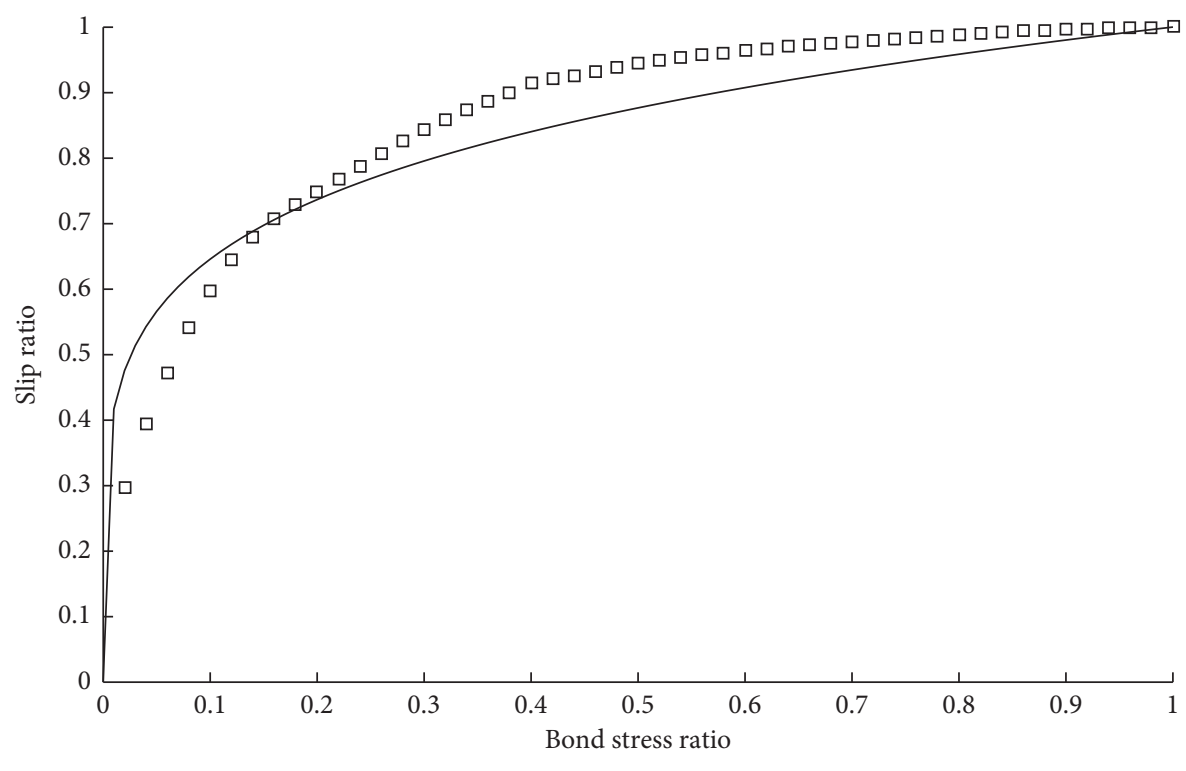

- Fitting curve

口 Experimental data

(c)

FIGURE 9: Continued. 


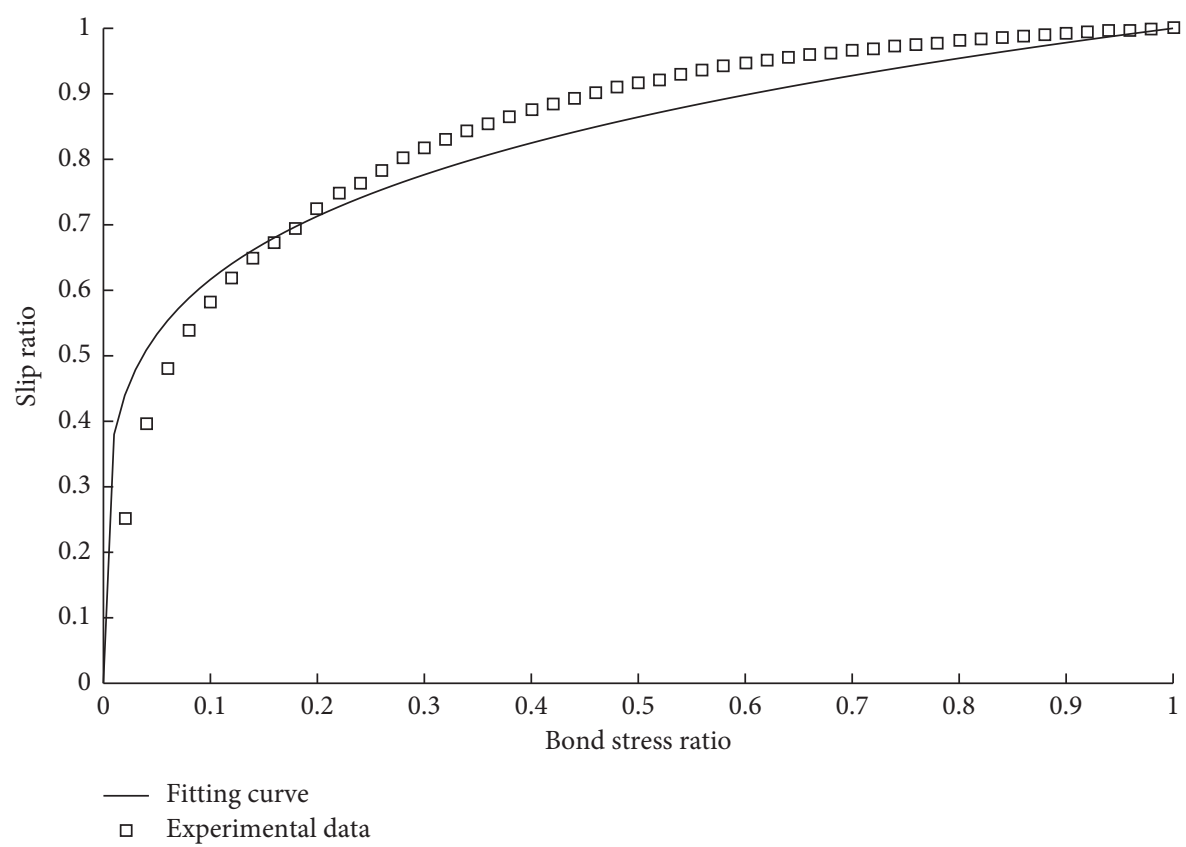

(d)

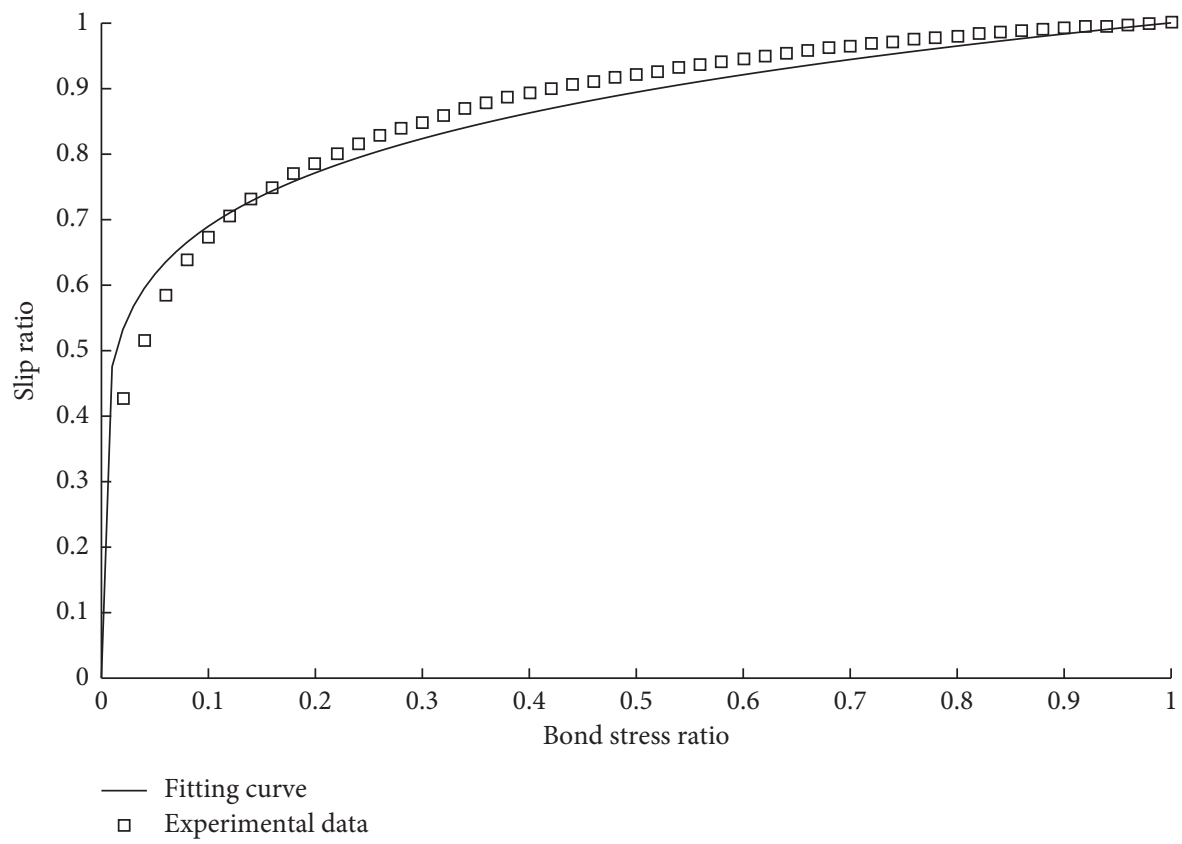

(e)

Figure 9: Relationship between stress ratio and slip ratio of different SAP contents. (a) 0 ; (b) $0.1 \%$; (c) $0.2 \%$; (d) $0.3 \%$; (e) $0.8 \%$.

where $f_{c u}$ is the compressive strength of SAP concrete, MPa; $f_{c, 28 d}$ is the 28-day compressive strength of ordinary concrete, $\mathrm{MPa} ; x$ is the SAP content, $\% ; f_{c}^{\prime}$ is the cylinder compressive strength, $\mathrm{MPa} ; \tau_{\max }$ is the bond strength, $\mathrm{MPa}$; $s_{0}$ is the slip at ultimate bond strength, $\mathrm{mm} ; \tau$ is the bond stress value, $\mathrm{MPa}$; and $s$ is the slip corresponding to bond stress, $\mathrm{mm}$.

The comparison between the theoretical value calculated according to formula (14) and the actual value in the test is shown in Figure 10. 


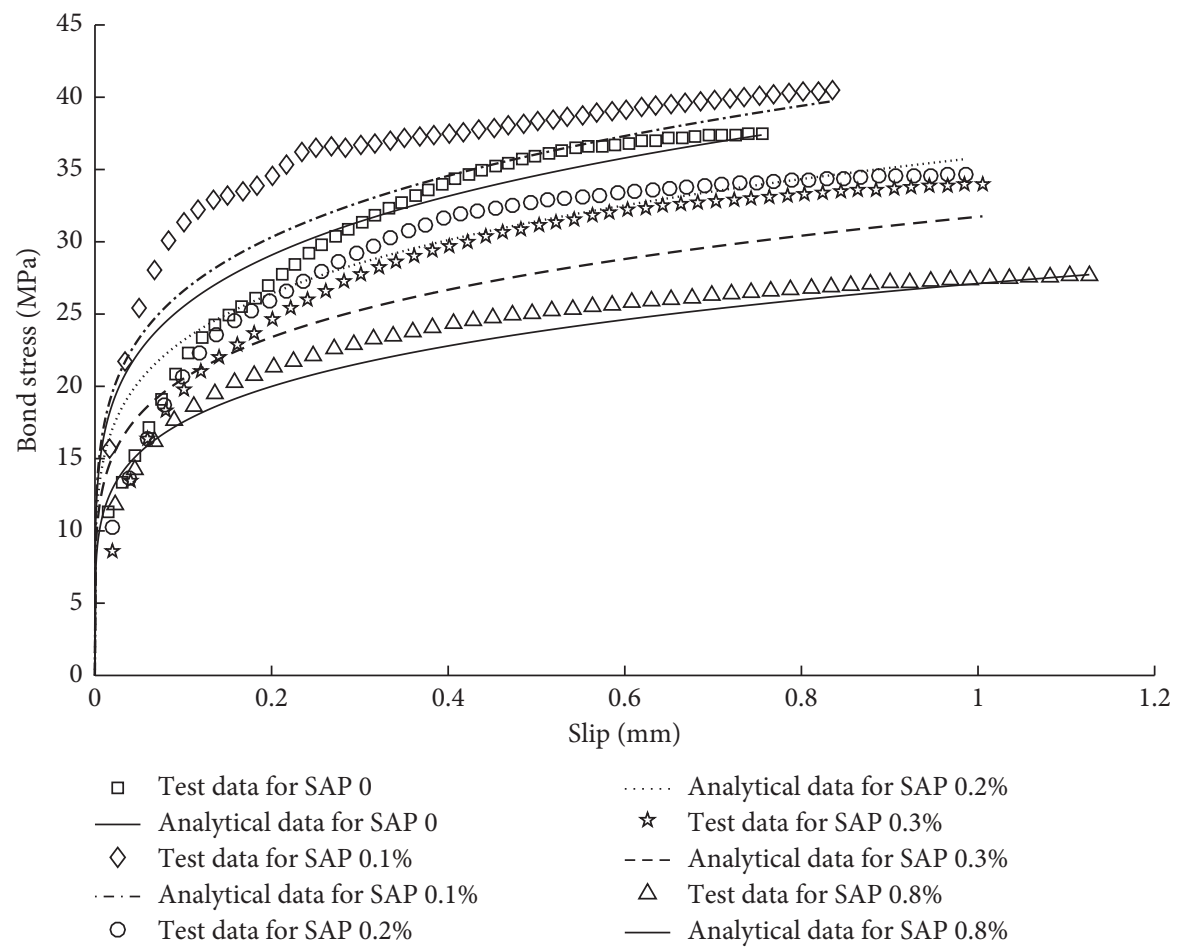

FIgURE 10: Theoretical and practical comparison of bond behavior of concrete mixed with SAP.

\section{Conclusions}

In this paper, through relevant tests and theoretical derivation, the bond behavior of concrete mixed with SAP was systematically studied, and the following conclusions were obtained:

(1) The compressive strength of HSC mixed with SAP first increases and then decreases with the increase of SAP content. The compressive strength of concrete with SAP content of $0,0.1 \%, 0.2 \%, 0.3 \%$, and $0.8 \%$ is $49.27,51.51,44.42,38.97$, and $32.85 \mathrm{MPa}$, respectively.

(2) With the increase of SAP content, the bond strength of HSC with SAP content first increases and then decreases. The bond strength of concrete with SAP content of $0,0.1 \%, 0.2 \%, 0.3 \%$, and $0.8 \%$ are, respectively, 36.76, 40.04, 34.56, 31.41, and 27.48 MPa.

(3) The bond strength of HSC mixed with SAP increases with the increase of its compressive strength, and a prediction model of the bond strength of SAP concrete is established.

(4) The slip corresponding to bond strength of HSC mixed with SAP decreases with the increase of compressive strength, and the prediction model of slip corresponding to bond strength of concrete mixed with SAP is established.

(5) A prediction model of stress-slip relationship between steel bars and HSC mixed with SAP was established, which was in good agreement with the experimental data and could be used to estimate the stress-slip relationship of HSC mixed with different SAP content.

\section{Future Work}

In this paper, compression and bond strength for HSC with various SAP content were determined from pull-out tests. The results presented can be utilized for determining the amount of SAP addition in engineering applications. Also, the slip-stress relationship developed in this study can be incorporated into the finite element analysis for structures. In addition, the slip-stress curve was developed for $50 \mathrm{MPa}$ compression strength HSC. The reason of not being able to obtain the descending portion after the ultimate bonding stress can be attributed to the high bond strength between HSC and the rebar. In the future, the bond strength for normal strength concrete should be compared with this study.

\section{Data Availability}

The research data used to support the findings of this study are available from the corresponding author upon request.

\section{Conflicts of Interest}

The authors declare that they have no conflicts of interest. 


\section{References}

[1] ACI Committee 363, 363R-10 Report on High-Strength Concrete, American Concrete Institute, Indianapolis, IN, USA, 2010.

[2] D. Shen, M. Wang, Y. Chen, W. Wang, and J. Zhang, "Prediction of internal relative humidity in concrete modified with super absorbent polymers at early age," Construction and Building Materials, vol. 149, pp. 543-552, 2017.

[3] D. P. Bentz, M. A. Peltz, and J. Winpigler, "Early-Age properties of cement-based materials. II: influence of waterto-cement ratio," Journal of Materials in Civil Engineering, vol. 21, no. 9, pp. 512-517, 2009.

[4] D. Shen, J. Jiang, W. Wang, J. Shen, and G. Jiang, "Tensile creep and cracking resistance of concrete with different waterto-cement ratios at early age," Construction and Building Materials, vol. 146, pp. 410-418, 2017.

[5] D. J. Shen, K. Q. Liu, Y. Ji, H. F. Shi, and J. Y. Zhang, "Early age residual stress and stress relaxation of fly ash high-performance concrete," Magazine of Concrete Research, vol. 72, no. 2, 2017.

[6] A. Bentur, S.-I. Igarashi, and K. Kovler, "Prevention of autogenous shrinkage in high-strength concrete by internal curing using wet lightweight aggregates," Cement and Concrete Research, vol. 31, no. 11, pp. 1587-1591, 2001.

[7] D. Shen, J. Jiang, Y. Jiao, J. Shen, and G. Jiang, "Early-age tensile creep and cracking potential of concrete internally cured with pre-wetted lightweight aggregate," Construction and Building Materials, vol. 135, pp. 420-429, 2017.

[8] J. Liu, C. Shi, X. Ma, K. H. Khayat, J. Zhang, and D. Wang, “An overview on the effect of internal curing on shrinkage of high performance cement-based materials," Construction and Building Materials, vol. 146, pp. 702-712, 2017.

[9] T. J. Barrett, I. De la Varga, and W. J. Weiss, "Reducing cracking in concrete structures by using internal curing with high volumes of fly ash," Structures Congress, vol. 46, pp. 699-707, 2012.

[10] X.-M. Kong, Z.-L. Zhang, and Z.-C. Lu, "Effect of pre-soaked superabsorbent polymer on shrinkage of high-strength concrete," Materials and Structures, vol. 48, no. 9, pp. 2741-2758, 2015.

[11] D. Shen, J. Jiang, M. Zhang, P. Yao, and G. Jiang, “Tensile creep and cracking potential of high performance concrete internally cured with super absorbent polymers at early age," Construction and Building Materials, vol. 165, pp. 451-461, 2018.

[12] J. Schlitter and T. J. Barrett, "Restrained shrinkage behavior due to combined autogenous and thermal effects in mortars containing super absorbent polymer (SAP)," in Proceedings of the International RILEM Conference on Use of Superabsorbent Polymers and Other New Additives in Concrete, pp. 233-242, Lyngby, Denmark, August 2010.

[13] D. Shen, X. Wang, D. Cheng, J. Zhang, and G. Jiang, "Effect of internal curing with super absorbent polymers on autogenous shrinkage of concrete at early age," Construction and Building Materials, vol. 106, pp. 512-522, 2016.

[14] L. Dudziak and V. Mechtcherine, "Enhancing early-age resistance to cracking in high-strength cement-based materials by means of internal curing using super absorbent polymers. Additions improving properties of concrete," RILEM Proceedings Pro, vol. 77, pp. 129-139, 2010.

[15] O. M. Jensen and P. Lura, "Techniques and materials for internal water curing of concrete," Materials and Structures, vol. 39, no. 9, pp. 817-825, 2006.
[16] O. M. Jensen and P. F. Hansen, "Water-entrained cementbased materials," Cement and Concrete Research, vol. 31, no. 4, pp. 647-654, 2001.

[17] O. M. Jensen and P. F. Hansen, "Water-entrained cementbased materials," Cement and Concrete Research, vol. 32, no. 6, pp. 973-978, 2002.

[18] S. Mönning and P. Lura, "Superabsorbent polymers-an additive to increase the freeze-thaw resistance of high strength concrete," in Advances in Construction Materials, C. U. Grosse, Ed., pp. 351-358, Springer, Berlin, Germany, 2007.

[19] L. Faping and L. Jiesheng, "Study on the properties and mechanism of mortars modified by super absorbent polymers," Journal of Testing and Evaluation, vol. 47, no. 2, pp. 1516-1532, 2019.

[20] H. AzariJafari, A. Kazemian, M. Rahimi, and A. Yahia, "Effects of pre-soaked super absorbent polymers on fresh and hardened properties of self-consolidating lightweight concrete," Construction and Building Materials, vol. 113, pp. 215-220, 2016.

[21] A. Mignon, D. Snoeck, D. Schaubroeck et al., "pH-responsive superabsorbent polymers: a pathway to self-healing of mortar," Reactive and Functional Polymers, vol. 93, pp. 68-76, 2015.

[22] D. Snoeck, D. Schaubroeck, P. Dubruel, and N. De Belie, "Effect of high amounts of superabsorbent polymers and additional water on the workability, microstructure and strength of mortars with a water-to-cement ratio of 0.50 ," Construction and Building Materials, vol. 72, pp. 148-157, 2014.

[23] S. Al-Hubboubi, T. al-Attar, H. Al-Badry, S. Abood, R. Mohammed, and B. Haddhood, "Performance of superabsorbent polymer as an internal curing agent for selfcompacting concrete," MATEC Web of Conferences, vol. 162, Article ID 02023, 2018.

[24] A. J. Klemm and K. S. Sikora, "The effect of superabsorbent polymers (SAP) on microstructure and mechanical properties of fly ash cementitious mortarsfly ash cementitious mortars," Construction and Building Materials, vol. 49, pp. 134-143, 2013.

[25] X. Bian, L. Zeng, Y. Deng, and X. Li, "The role of superabsorbent polymer on strength and microstructure development in cemented dredged clay with high water content," Polymers, vol. 10, no. 10, p. 1069, 2018.

[26] P. Lura, O. M. Jensen, and S.-I. Igarashi, "Experimental observation of internal water curing of concrete," Materials and Structures, vol. 40, no. 2, pp. 211-220, 2007.

[27] H. Zhu, Z. Wang, J. Xu, and Q. Han, "Microporous structures and compressive strength of high-performance rubber concrete with internal curing agent," Construction and Building Materials, vol. 215, pp. 128-134, 2019.

[28] B. P. Hughes and C. Videla, "Design criteria for early-age bond strength in reinforced concrete," Materials and Structures, vol. 25, no. 8, pp. 445-463, 1992.

[29] R. A. Chapman and S. P. Shah, "Early-age bond strength in reinforced concrete," ACI Materials Journal, vol. 84, no. 6, pp. 501-510, 1988.

[30] X. Song, Y. Wu, X. Gu, and C. Chen, "Bond behaviour of reinforcing steel bars in early age concrete," Construction and Building Materials, vol. 94, pp. 209-217, 2015.

[31] X. L. Tang, Y. H. Qin, and W. J. Qu, "Experimental study on time-varying regularity of compressive and bond strength of concrete at early-age," Journal of Building Materials and Structures, vol. 30, no. 4, pp. 145-150, 2009. 
[32] X. Fu and D. D. L. Chung, "Decrease of the bond strength between steel rebar and concrete with increasing curing age 11 Communicated by D.M. Roy," Cement and Concrete Research, vol. 28 , no. 2, pp. 167-169, 1998.

[33] C. O. Orangun, J. O. Jirsa, and J. E. Breen, "A revaluation of test data on development length and splices," Journal of ACI, vol. 74, no. 3, pp. 114-122, 1977.

[34] D. Darwin, M. L. Tholen, E. K. Idun, and J. Zuo, "Splice strength of high relative rib area reinforcing bars," American Concrete Institute Structural Journal.vol. 93, no. 1, pp. 95-107, 1996.

[35] ACI Committee 408, Bond and Development of Straight Reinforcing Bars in Tension, ACI 408R-03, American Concrete Institute, Indianapolis, IN, USA, 2003.

[36] R. Eligehausen, E. P. Popov, and V. V. Bertero, Local Bond Stress-Slip Relationships of Deformed Bars under Generalized Excitations, University of California, Berkeley, CL, USA, 1983.

[37] M. R. Esfahani and B. V. Rangan, "Bond between normal strength and high strength concrete (HSC) and reinforcing bars in splices in beams," ACI Structural.Journal, vol. 95, no. 3, pp. 272-280, 1998.

[38] M. N. S. Hadi, "Bond of high strength concrete with high strength reinforcing steel !2008-07-24 !2008-10-28 !200811-26 !" The Open Civil Engineering Journal, vol. 2, no. 1, pp. 143-147, 2008.

[39] J. Zuo and D. Darwin, "Splice strength of conventional and high relative rib area bars in normal and high-strength concrete," ACI Structural Journal, vol. 97, no. 4, pp. 630-641, 2000.

[40] J.-Y. Lee, T.-Y. Kim, T.-J. Kim et al., "Interfacial bond strength of glass fiber reinforced polymer bars in high-strength concrete," Composites Part B: Engineering, vol. 39, no. 2, pp. 258-270, 2008.

[41] R. Okelo and L. R. Yuan, "Bond strength of fiber reinforced polymer rebars in normal strength concrete," Journal of Composites for Construction, vol. 9, no. 3, pp. 203-213, 2014.

[42] D. Shen, X. Shi, H. Zhang, X. Duan, and G. Jiang, "Experimental study of early-age bond behavior between high strength concrete and steel bars using a pull-out test," Construction and Building Materials, vol. 113, pp. 653-663, 2016.

[43] Comité Euro-International du Béton (CEB-FIP), CEB-FIP Model Code 2010, in First Completed Draft, Comité Euro-International du Béton, Lausanne, Switzerland, 2010.

[44] China Ministry of Construction, Chinese Standard GB 500102010, Code for Design of Concrete Structures, China Ministry of Construction, Beijing, China, 2010.

[45] M. H. Harajli, M. Hout, and W. Jalkh, "Local bond stress-slip behavior of reinforcing bars embedded in plain and fiber concrete," ACI Materials Journal, vol. 92, no. 4, pp. 343-353, 1995.

[46] M. Harajli, B. Hamad, and K. Karam, "Bond-slip response of reinforcing bars embedded in plain and fiber concrete," Journal of Materials in Civil Engineering, vol. 14, no. 6, pp. 503-511, 2002.

[47] Y. L. Xu and W. D. Shen, "Experimental study of bond behavior of reinforced concrete," Journal of Building Materials and Structures, vol. 15, no. 3, pp. 26-37, 1994.

[48] J. M. Alsiwat and M. Saatcioglu, "Reinforcement anchorage slip under monotonic loading," Journal of Structural Engineering, vol. 118, no. 9, pp. 2421-2438, 1992.

[49] E. Cosenza, G. Manfredi, and R. Reallfonzo, "Analytical modeling of bond between FRP reinforcing bars and concrete," in Proceedings of the 2nd International RILEMS Ymposium, pp. 164-171, London, UK, August 1995.
[50] B. Tighiouart, B. Benmokrane, and D. Gao, "Investigation of bond in concrete member with fibre reinforced polymer (FRP) bars," Construction and Building Materials, vol. 12, no. 8, pp. 453-462, 1998.

[51] J. Y. Lee, C. K. Yi, Y. G. Cheong, and B. I. Kim, "Bond stressslip behaviour of two common GFRP rebar types with pullout failure," Magazine of Concrete Research, vol. 64, no. 7, pp. 575-591, 2012.

[52] ASTM, Standard Specification for Lightweight Aggregate for Internal Curing of Concrete, ASTM International, West Conshohocken ,PA, USA, 2013.

[53] RILEM/CEB/FIP, Recommendations on Reinforcement Steel for Reinforced Concrete, CEB News, Lausanne, Switzerland, 1983. 